\title{
THE EFFECT OF IMPLEMENTING PREVIEW QUESTION READ REFLECT RECITE READ AND READ (PQ4R) LEARNING MODEL INTEGRATED MNEMONIC MODULE TO LEARNING OUTCOMES AND RETENTION OF STUDENTS
}

\author{
Muhibbuddin $^{1 \star}$, Nadia Rahmi ${ }^{2}, \&$ Safrida $^{3}$ \\ ${ }^{1}$ Dr., Syiah Kuala University, Banda Aceh, Indonesia, muhibbuddin@unsyiah.ac.id \\ ${ }^{2}$ Syiah Kuala University, Banda Aceh, Indonesia, nadiarahmi.95@gmail.com \\ ${ }^{3}$ Dr., Syiah Kuala University, Banda Aceh, Indonesia, saf_rida@unsyiah.ac.id \\ ${ }^{*}$ Corresponding Author
}

\begin{abstract}
Low students' learning outcomes and retention are among the problems in learning. An innovation in the learning process is thus needed to solve the problems. The effect of Preview, Question, Read, Reflect, Recite, Review and Read (PQ4R) learning model integrated with a mnemonic-based module is one of the useful alternatives to overcome the problems. This study aims to address the question on how the integration between the PQ4R learning model and a mnemonic-based module affects the students' learning outcomes and retention. This study used an experimental method with a Quasi-Experimental design. The research subjects were 124 students who were selected purposively from four parallel classes in one high school in Banda Aceh, Indonesia, from a total population of 16 public high schools in Banda Aceh. The subjects were divided into two groups, namely the experimental and control group; each of which consisted of 62 students. In the experimental group, the PQ4R model combined with mnemonic-based modules was used, while in the control group, PQ4R with a conventional learning module was applied. The measured parameters were the students' learning outcomes and retention. To examine the significance of learning outcomes between the experimental and control group, the Analysis of Covariance (ANCOVA) statistical test was employed. The data for retention were obtained from the results of posttest, retention test-1 (retest-1) and retention test-2 (retest-2). The retention was analyzed by using a recognition method. The results showed that there is a significant difference between the learning outcomes of the students in the experimental class and those of the students in the control class. The experimental class has a better retention rate compared to that of the control class. Thus, the application of the PQ4R learning model combined with a mnemonic based module can positively contribute to improving students' learning outcomes and retention.
\end{abstract}

Keywords: Mnemonic, Learning Outcomes, Retention.

\section{INTRODUCTION}

Poor comprehension and retention skill of students are among the most common issues in learning. However, students' comprehension of concepts can be improved through the use of appropriate media or teaching materials during the learning process. Teaching materials can be designed based on the needs of the students and the characteristics of material to be taught. One form of teaching materials is a module, 
which can facilitate students' understanding of learning concepts and the retention of information being learnt (Cromley \& Synder, 2007).

Students' ability to understand the learning concepts can also be improved through the use of learning strategies that place emphasis on understanding the basic concepts of the material to be taught. The effectiveness of a learning strategy should not only be assessed from the students' mastery levels of concepts, but also from the length of time that the concepts are retained within their memory because forgetfulness may occur if the learning is a mere knowledge transfer (Yaumul, 2016).

Based on the findings of a preliminary study carried out on two Biology teachers at a high school, some topics were found to be highly difficult for the students to understand. One of which was human body's defense system which discusses body's protection against foreign objects/diseases that invade the body. There were a number of topic-related terms in the explanation that seemed to cause an understanding and retention difficulty of the students.

The mean evaluation score for this topic was 70 , which was below the minimum passing criteria (75), thus requiring an improvement. This can be seen from the rate of students' classical learning completeness from the last three years (2017-2019) which only reached $67.50 \%$ below the minimum rate of classical learning completeness (85\%). This low rate is assumed to be caused by the use of inappropriate teaching materials during the learning process, resulting in the students' lack of interest in classroom participation. When the students feel less interested in learning, their ability to retain the information during the learning process can be affected.

The level of students' comprehension of concepts and retention can be improved by increasing their engagement in the learning process (Dresler et al., 2017). One strategy that facilitates students' understanding of concepts as well as improving their retention is a Mnemonic-based learning strategy. A mnemonic-based module is among the appropriate ways to encode information, which enables the students to understand and remember the information easily. One basic principle of mnemonic strategy is to help the information go into the long-term memory, so that it can be retained longer in mind (Midany \& Mostafa, 2017). There have been a number of studies carried out on the use of mnemonic strategy to improve students' learning outcomes and retention (Benjamin, 2017; Dretzkea \& Levinb, 1996; Franke at al., 1991; Loache \& Todd, 1998; Manalo et al., 2013; Marzban \& Azimi., 2012; Mostafa, 2016; Nelson et al., 2013; Richter et al., 2016; Rawendy et al., 2017; Simon et al., 2017; Vlasceanu \& Coman, 2018; Wyra et al., 2007). However, these studies only focused on the effects of mnemonics on the students' learning outcomes and retention. They did reveal that the use of mnemonics was able to promote the students' interest, positive responses and improvement in the learning outcomes; however, they did not mention the extent to which it improved the students' learning outcomes and retention. In addition, they only focused on the application of mnemonics on non-biological topics and was not integrated with any modules. Therefore, the application of PQ4R learning model combined with a mnemonic-based module needs to be explored. This current research was thus conducted to find out the effects of the use of PQ4R learning model integrated with a mnemonicbased module on students' learning outcomes and retention on a specific biological topic, namely human body's defense system.

The PQ4R learning model can help students remember what they read. PQ4R stands for Preview, Question, Read, Reflect, Recite, and Review (Trianto, 2007). Previewing and asking questions prior to reading reactivates the previously learned knowledge and initiates the process of connecting the newly gained information with the previously learned one. This model is used to help students remember what they have read and facilitate a learning process that starts with reading activities (Setiawati \& Corebima, 2018). Appropriate reading activities will enable students to absorb the main points of their reading (Wahyuningsih, 2012). The PQ4R Learning Strategy is student-centered, allowing the students to build their own knowledge of the topic being taught (Maesah et al., 2012).

\section{RESEARCH METHOD}

The method used in this research was the Quasi-Experimental method with the Pretest-Posttest NonEquivalent Control Group design. The research design is as presented in Table-1 (Gall et al., 2003). 
Table-1. Pretest-Posttest Non-Equivalent Control Group Design

\begin{tabular}{|c|c|c|c|c|c|c|}
\hline Sample & Group & Pretest & Treatment & Posttest & Retest-1 & Retest-2 \\
\hline Non random & $\mathrm{A}$ (Experiment) & $\mathrm{P}$ & $\mathrm{X}_{1}$ & $\mathrm{P}_{1}$ & $\mathrm{P}_{2}$ & $\mathrm{P}_{3}$ \\
\hline Non-random & $\mathrm{B}$ (Control) & $\mathrm{K}$ & $\mathrm{X}_{2}$ & $\mathrm{~K}_{1}$ & $\mathrm{~K}_{2}$ & $\mathrm{~K}_{3}$ \\
\hline
\end{tabular}

Description:

$\mathrm{P}=$ pretest (initial test)

$\mathrm{X}_{1}=$ treatment (treatment in experimental class).

$\mathrm{X}_{2}=$ treatment (treatment in control class).

$\mathrm{P}_{1}=$ posttest (final test) after the treatment in experimental class.

$\mathrm{K}_{1}=$ posttest (final test) after the treatment in control class.

$\mathrm{P}_{2}=$ retest -1 , conducted 2 weeks after the posttest was carried out in the experimental class.

$\mathrm{P}_{3}=$ retest -2 , conducted 3 weeks after the posttest was carried out in the experimental class.

$\mathrm{K}_{2}=$ retest -1 , conducted 2 weeks after the posttest was carried out in the control class.

$\mathrm{K}_{3}=$ retest -2 , conducted 3 weeks after the posttest was carried out in the control class.

The research subjects were 124 students who were selected purposively from four parallel classes in one high school in Banda Aceh, Indonesia, from a total population of 16 public high schools in Banda Aceh. The subjects were divided into two groups, namely the experimental and control classes; each of which consisted of 62 students chosen non-randomly. The PQ4R learning model with a mnemonic-based module was used in the experimental class while PQ4R with a conventional learning module was utilized in the control class. The research took 30 days in June 2020.

The parameters measured for data collection were the students' learning outcomes and retention. The data for learning outcomes ware obtained from a pretest and posttest. The test instrument was a multiple-choice objective test consisting of 50 items. Retention data were obtained from posttest data, the first retention test (retest-1), and the second retention test (retest-2). The first retention test was conducted two weeks after learning had finished, while the second retention test was conducted three weeks after learning had finished (Hake, 2007).

\section{DATA AND ANALYSIS}

The data of learning outcomes were analyzed by using a parametric statistical analysis, namely Covariance Analysis (ANCOVA) to examine the significance of learning outcomes between the experimental group and control group. The data of retention was obtained from the results of the posttest, retention test- 1 (retest-1) and retention test-2 (retest-2), which were analyzed by using the Independent sample t-test at a significant level of 0.05 . The retention percentage was calculated by using a recognition method, namely comparing the average retest score with the average posttest score.

\section{RESULT AND DISCUSSION}

\subsection{The Students' Learning Outcomes}

The data on the initial ability and learning outcomes of students in the experimental class and the control class are presented in Figure-1. The average score of the experimental class pretest was 54.19 and the control class was 53.77. The difference between the pretest mean score of the experimental class and the control class is 0.42 . The results of the difference test (ANCOVA) on the learning outcomes showed no significant difference. This suggests that the students in both classes had the same initial knowledge and ability in understanding the immune system material. After the treatment was given, the average post-test score increased by 83.03 from the pretest 54.19 . When the posttest's mean scores of both groups were compared, it was found that the score of the experimental group met the Minimum Completeness Criteria (KKM) set by the school, namely 75. ANCOVA test results (Table-2) showed that there was a significant difference between the two $\left(F_{\text {cal }} 137,67>F_{\text {table }} 4.00\right)$. 


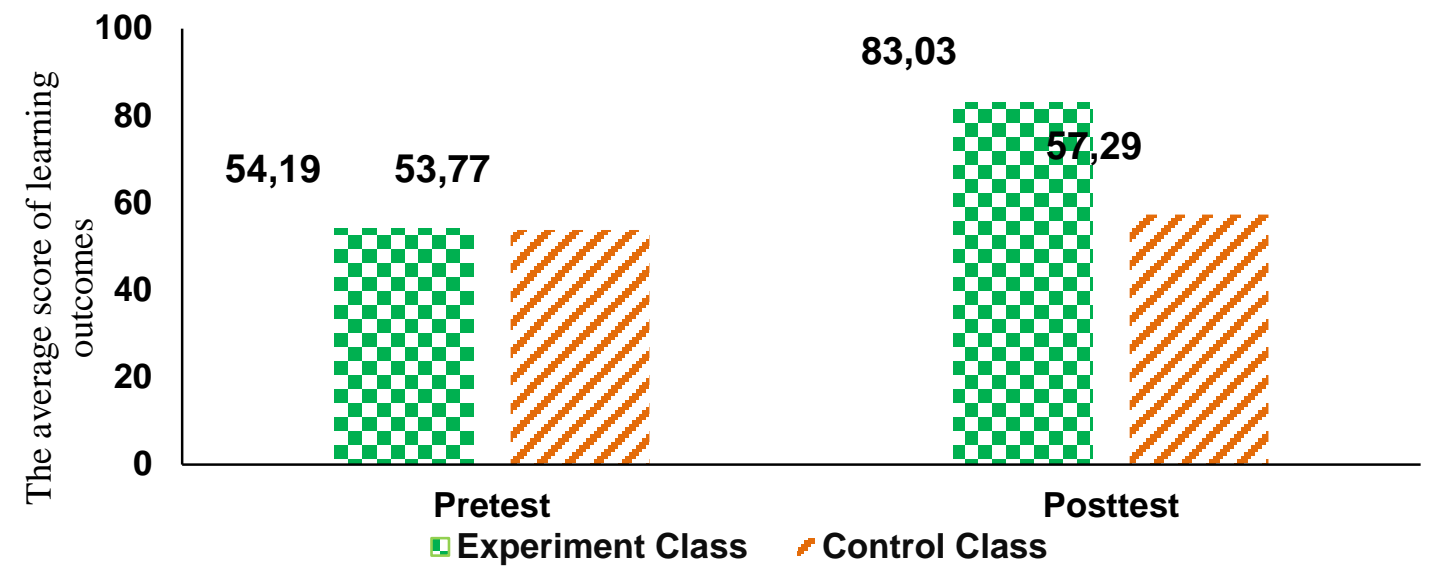

Figure-1. The average score of students' learning outcomes from experimental class andcontrol class

Covariance analysis (Table-2) examined the effects of the application of PQ4R learning model combined with a mnemonic-based module on the human body's defense system topic. The results showed that there is a significant difference between the learning outcomes of the experimental group and those of control group, suggesting that the application of the two has an effect on the students' academic attainments.

Table-2. The ANCOVA data of students' learning outcomes from the experimental and control class

\begin{tabular}{|l|c|c|c|c|c|}
\hline Source of Variations & $\begin{array}{c}\text { Total corrections in } \\
\text { squares }\end{array}$ & $\begin{array}{c}\text { egrees of } \\
\text { freedom }\end{array}$ & $\begin{array}{c}\text { Total average of } \\
\text { correction in squares }\end{array}$ & F-Calculate & $\begin{array}{c}\text { F-table (0.05) } \\
\mathrm{df}=1: 122)\end{array}$ \\
\hline Among treatment & $20.333,30$ & 1 & $20.333,30$ & $\left.137,67^{\star}\right)$ & 4,00 \\
\hline Error-Y & $18.018,72$ & 122 & 147,69 & \\
\hline Total & $38.352,02$ & 123 & & & \\
\hline
\end{tabular}

Description: *) Significantly difference

The improvement in the experimental group's learning outcomes was the result of the use of PQ4R learning model and a mnemonic-based module. The module contained a set of teachers' real actions with the utilization of certain techniques, such as coding/abbreviating technical terms, using keywords, and supporting images that were deemed to be more effective and efficient at improving students' understanding of concepts, as what was in the current research on the topic of human body's defense system. This topic is often perceived as a complex topic by many students because it relates to body organs that play a role in body protection against foreign invaders, a number of mechanisms of internal body protection, and technical terms specific to the topic. The integration between PQ4R learning model and a mnemonic-based module is thus highly effective to be applied to this topic because it can facilitate the learning, improve the students' understanding, and create a more meaningful learning.

The mnemonic-based module was also designed to be more interesting than the ordinary module. It contained a detailed information and supporting images, helping to promote the students' understanding and motivation in learning. PQ4R learning model with a mnemonic-based module was successful in inducing students' active participation, such as answering questions, expressing opinions, and completing student worksheets distributed by the teacher. In addition, they were able to understand the topic easily and quickly because it was equipped with key words, abbreviations and meanings of the topic-related terms that were easy to understand and remember.

There are several factors that facilitate a learning process, namely good wellbeing of students, the readiness of teachers, the appropriateness of teaching materials, and a conducive learning environment. The use of a mnemonic-based module with PQ4R learning model on the topic of human body defense system is therefore effective because it projects the teacher's readiness and the appropriateness of teaching materials, creates a conducive learning atmosphere, and enhances the students' ability to achieve the learning indicators and optimal outcomes. The effects of the two on the learning outcomes were noticeable from the outcomes 
achieved by the experimental group, which were significantly different from those in the control group that only utilized a conventional module, resulting in lower classroom participation. In the control group, only a few students were found to be actively involved in giving opinions, asking questions and completing the student worksheets. This indicates nonoptimal learning outcomes, marked by the incompleteness of most learning outcomes of the students.

Mnemonic strategies such as visualization with the use of images can directly affect and accelerate the information retrieval (Erickson, 2014). They can also reduce the risks of students' forgetfulness and improve the information retrieval to a very high level (Ruth et al., 2013). This was proven by the mean score of the experimental group's learning outcomes that was much higher than that of the control group after receiving the treatment consisting of PQ4R learning model and a mnemonic-based module. The application of the two enhanced the students' academic attainment by increasing their motivation, active participation, and direct involvement in the learning. In addition, the combination of the two helped the students solve a problem more easily and relate the topic to actual events in their surroundings. This way allows them to achieve the learning indicators with optimal learning results (Siahaan, 2017).

\subsection{Students' Retention}

Retention data were obtained from retention tests (retest- 1 and retest-2) carried out in the second and third week after the learning process was completed. The comparison of the posttest's mean scores and the retention tests' mean scores is presented in Figure-2.

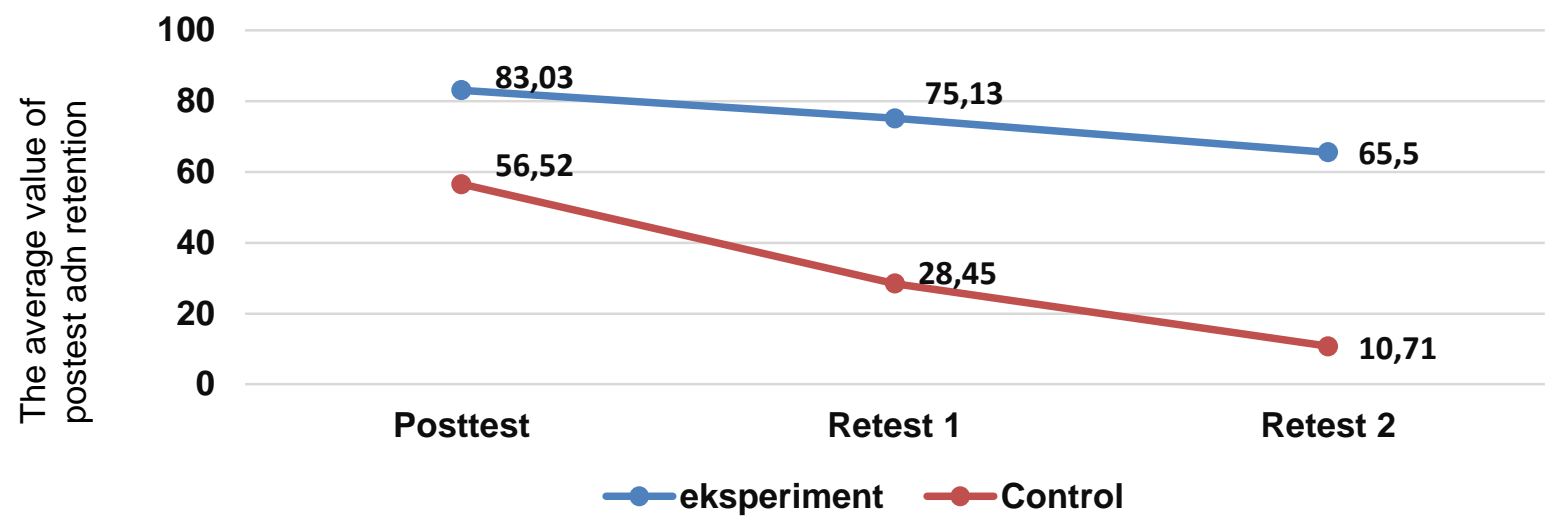

Figure-2. The comparative value between posttest and retention test

The data in Figure-2 shows that the retention of students after two weeks of the learning process decreased. Retention in the control class decreased more significantly than that of the control class. The average posttest score of the experimental class was 83.03, which decreased to 75.13 after the retention 1 test (retest-1) carried out in the second week after learning, with the mean difference of 7.9 between the two delivered tests. The post-test's mean score of control class, however, was 56.52, which decreased to 28.45 in the retention test- 1 with the mean difference of 28.07 between the posttest and retest-1. Decreased retention at retest- 2 occurred in both classes (experimental and control class). The retention reduction rate was higher in the control class than that in the experimental class (Figure-2).

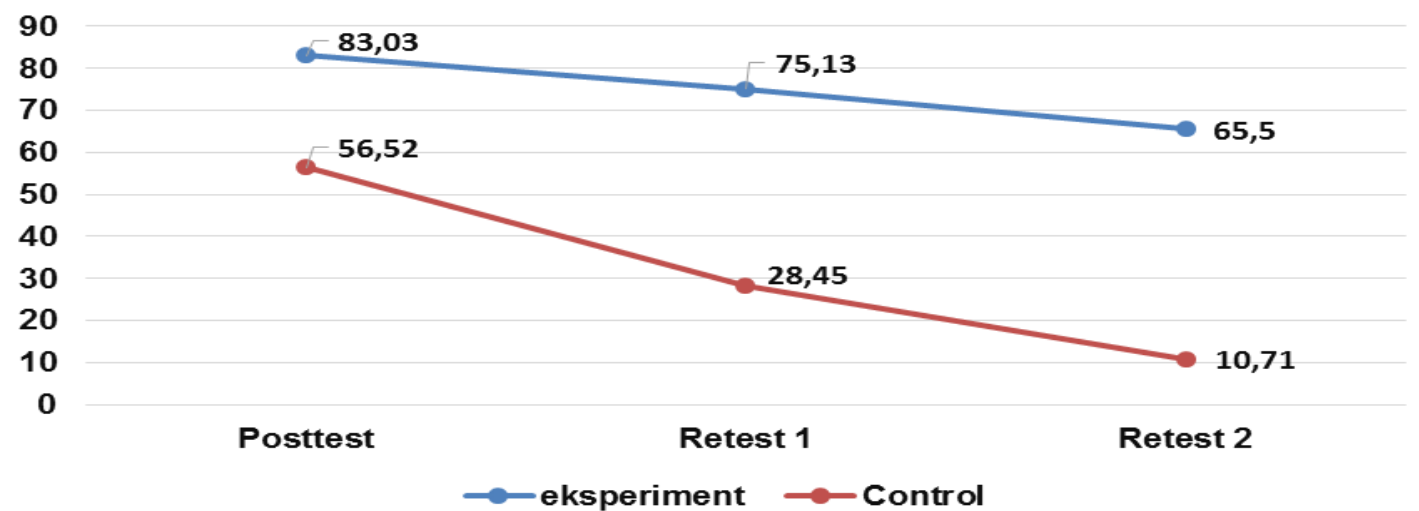

The results of difference retention tests (retest-1 and retest-2) showed a significant difference between the 
experimental class and the control class (Table-3).

Table-3. The average difference test of Retest-1 in the experimental class and control class.

\begin{tabular}{|c|c|c|c|c|}
\hline \multicolumn{5}{|c|}{ Retest-1 } \\
\hline Class & Average & Normality *) & Homogeneity **) & Significance ${ }^{* \star *}$ ) \\
\hline Experiment & 75,13 & $\begin{array}{c}\text { Normal } \\
\text { Sig: } 0,060\end{array}$ & \multirow{2}{*}{$\begin{array}{l}\text { Homogeny } \\
\text { Sig: } 0,376\end{array}$} & \multirow{2}{*}{$\begin{array}{c}\mathrm{t} \text {-cal }>\mathrm{t} \text {-table } \\
23,107>1,9796 \\
\text { Sig (2-tailed): } 0,000\end{array}$} \\
\hline Control & 28,45 & $\begin{array}{l}\text { Normal } \\
\text { Sig:0,083 }\end{array}$ & & \\
\hline \multicolumn{5}{|c|}{ Retest-2 } \\
\hline Experiment & 65,5 & $\begin{array}{c}\text { Normal } \\
\text { Sig:0,070 }\end{array}$ & \multirow{2}{*}{$\begin{array}{l}\text { Homogeny } \\
\text { Sig: } 0,576\end{array}$} & \multirow{2}{*}{$\begin{array}{c}t-\text { cal }>t{ }^{-} \text {table } \\
38,992>1,9796 \\
\text { Sig }(2 \text {-tailed }): 0,000\end{array}$} \\
\hline Control & 10,71 & $\begin{array}{c}\text { Normal } \\
\text { Sig: 0,081 }\end{array}$ & & \\
\hline
\end{tabular}

Description:

$\left.{ }^{*}\right)=$ Kolmogorov-Smirnov Test (Normal, Sig. $>$ a 0,05)

$\left.{ }^{* *}\right)=$ Levene Test $($ Homogen, Sig. $>$ a 0,05)

$\left.{ }^{* * *}\right)=$ Independent Sampel $t$-Test (Significant, Sig. (2-tailed) $<\alpha 0,05$.

Based on the retests' results of the experimental and control class (Table-3), it is believed that the application of the PQ4R learning model combined with a mnemonic-based module decreased student retention. The decrease in retention of the control class was more significant than that of the experimental class. The comparison of both groups' retention rates is presented in Figure-3.

The data in Figure-3 shows that the retention rate of those in the experimental group after two weeks of learning was $90.69 \%$, which belongs to a very good category. This suggests that the concepts related to the topic of human body's defense system are remembered well by students. However, the percentage of retention- 1 in the control class only reached $50.75 \%$, which belongs to the poor category. This indicates the students' low memory of the topic because the material presented with conventional module was still poorly understood and remembered.

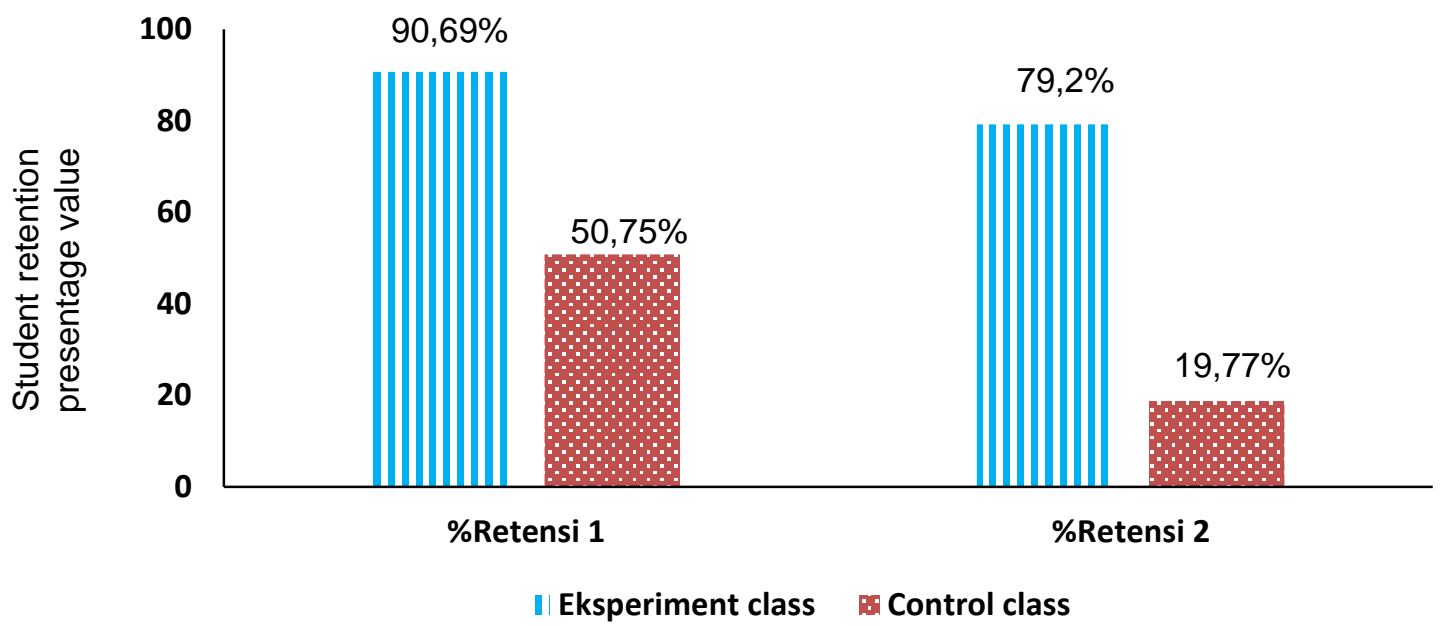

Figure-3. The presentage of retention test-1 and test-2 
There was a decrease in the retest- 2 percentage of the experimental class compared to the percentage of retest-1. Despite the decrease, the retest-2 percentage of this group was still above the minimum standard, with the rate of $79.2 \%$. This shows that the students' retention of the topic was good because the previously learned material was stored well in their memory. The rate of retention test- 2 of control class, however, only reached 19.77, which was below the minimum standard. This suggests that the student's retention was poor because the previously gained information was not retained well in their memory.

Higher retention of the students in the experimental group appeared to be the result of the integration between the PQ4R learning model and a mnemonic-based module containing acronyms, images, and keywords. The module specifically designed for the topic of human body's defense system is an appropriate way to encode the information so that it can be remembered easily by the students. In addition, it allows the information to be retained in their long-term memory. One example of the acronyms used was ADEGM to facilitate the retention of five types of immunoglobins in the body, namely Immunoglobin $\mathbf{A}$, Immunoglobin $\mathbf{D}$, Immunoglobin $\mathbf{E}$, Immunoglobin $\mathbf{G}$, and Immunoglobin $\mathbf{M}$. Combining the initial letters of these types is one way to help the information be stored and recalled easily.

The application of PQ4R learning combined with a mnemonic-based module also allows an easy and quick information retention because the module is not only equipped with the material but also images that make it interesting. A mnemonic-based module can make the material more meaningful and assist students in remembering the previously learned information easily through the coding methods or the use of terms that are easy to remember. Students' involvement in learning activities will, in turn, increase their memory retention. The use of a mnemonic-based module can also encourage the students to be more creative and motivated in learning topic-specific terms that they may find difficult to understand and remember. In addition, the module can help them obtain a clear picture and develop a deep understanding of the topic that will increase their retention. With high retention ability, they will be able to mentally store the information appropriately and retrieve it for the upcoming activities.

The decrease in the retention rate in test-2 occurred because the students were no longer studying the same topic at the time of the test. The topic of human body's defence system had been finished; thus, the information recall became disrupted. In addition, prior to re-test 2, the students had not been informed that the test material was going to be the same as that given during the posttest. The previously gained information was thus not fully stored in the memory because forgetfulness happened. A person may experience this when the newly learnt information causes problems and inhibits the recall of the previously learned information. In this case, reproducing or retrieving the past information is difficult to do (Irham, 2013).

There are several factors affecting retention, namely: 1) selection of the learning strategies/learning models; 2) material characteristics; 3) students' academic skills; 4) the timing of the retention test; 5) internal factors. Based on the findings of retest-1 and retest-2, a combination of PQ4R learning and a mnemonic-based module was found to successfully increase the students' retention. This can be seen from the results of retest1 carried out at interval of two weeks. Material characteristics were found to affect the size of the retention value, and in this case, the level of material's difficulty belongs to the high-level cognitive category (Irham, 2013). The results suggested that the students with low level of academic skill should be taught with appropriate learning strategies and teaching materials, such as a mnemonic-based module. Retention refers to the remaining memory after forgetfulness happens, and in this study, it was disrupted because the retention tests were carried out in the second or third week after learning. Furthermore, prior to the retention test, the teaching and learning process in both classes was still ongoing with a different topic, causing the newly learned information to be more memorable than that learned two weeks ago. This consequently affected the results of the next retention test because the students tended to remember what they currently learned rather than what they had learned some time ago.

Student retention refers to students' ability to absorb and retain information in their long-term memory (Dresler et al., 2017). Whether or not a learning is well-understood and absorbed by the students can be measured from their retention power. High retention generally indicates students' active behaviours in learning, allowing them to understand and remember the information thoroughly. One way allowing an easy and optimal information production and retention improvement up to $90 \%$ in the long-term memory is through the application of mnemonic strategy (Rawendy et al., 2017). Using this strategy in the form of visualization (pictures), for instance, can minimize the risks of forgetting the information to the lowest level and reinforce the information retrieval to a very high level. In addition, encoding the technical terms related to the topic being discussed can facilitate students' comprehension and retention (Marzban \& Azimi, 2012).

\section{CONCLUSION AND RECOMMENDATION}

The application of the PQ4R learning model combined with a mnemonic module has significant effects on the 
students' learning outcomes in the experimental class compared to those of the control class taught with a conventional module. The experimental class was found to have a better retention rate compared to that of the control class. Thus, the application of the PQ4R learning model integrated with a mnemonic-based module can be a good alternative to improving students' learning outcomes and retention. The application of the two was proven to have positive impacts on the learning outcomes and retention; however, a decrease in the students' retention still occurred. Therefore, a further study on the use of PQ4R model with mnemonicbased module is still necessary to prevent a decrease in student retention.

\section{REFERENCE LIST}

Benjamin, S. (2017). Combined mnemonic strategy training and high-definition transcranial direct current stimulation for memory deficits in mild cognitive impairment. Alzheimer's and Dementia: Translational Research and Clinical Interventions, 3(3):459-470.

Cromley, J. \& Snyder, L.E. (2007). Testing the Fit of the DIME Model of Reading Comprehension with Biology Text. Journal of educational Phsychology, 102(3):687-700

Dresler, M.; Shirer, W. R.; Konrad, B. N.; Müller, N. C. J.; Wagner, I. S.; Fernández, G..; Czisch, M. \& Greicius, M. D. (2017). Mnemonic Training Reshapes Brain Networks to Support Superior Memory. Neuron, 93(5):1227-1235.

Dretzkea, B. J. \& Levinb, J. R. (1996) Assessing Students' Application and Transfer of a Mnemonic Strategy: The Struggle for Independence. Contemporary Educational Psychology. 21(1):83-93.

Erickson, J. (2014). Changing Zaire to Congo: The fate of no-longer relevant mnemonic information. Neurolmage, 101(2):1-7.

Franke, T. M.; Levin, J. R. \& Carney, R. N. (1991). Mnemonic artwork-learning strategies: Helping students remember more than "Who painted what?". Contemporary Educational Psychology,16(4):375-390.

Gall, M. D.; Gall,J.P \& Brog, W.R. 2003. Educational Research An Introduction Boston: Pearson Education Inc.

Hake, R. R. (2007). Interactive-engagement versus traditional methods: A six Thousand-student survey of mechanics test data for introductory physics courses. American Journal of Phyysics, 66(1):64-74.

Irham, M. (2013). Psikologi Pendidikan, Jogjakarta: Ar-Ruus Media.

Loache, J. S. D. \& Todd, C.M. (1988). Young children's use of spatial categorization as a mnemonic strategy. Journal of Experimental Child Psychology, 46(1):1-20.

Maesah, I.; Odig, S.; \& Retnowati, R. (2012). The implementation of PQ4R (Preview, Question, Read, Reflect, Recite, and Review) and Talking Stick in science learning to Improve Learning Outcomes of Grade VII Junior high school IT AL-Muttaqien, E-Journal Universitas Pakuan, 1(1):1-13.

Manalo, E.; Uesaka, Y. \& Sekitani, K. (2013). Using mnemonic images and explicit sound contrasting to help Japanese children learn English alphabet sounds. Journal of Applied Research in Memory and Cognition, 2(4):216-221

Marzban, A. \& Azimi, F. (2012). The effect of mnemonic strategies instruction on the immediate and delayed information retrieval of vocabulary learning in EFL learners. World Applied Sciences Journal, $17(4): 458-466$.

Midany, A. A. H. \& Mostafa, E. A. (2017). Review of mnemonic devices and their applications in cardiothoracic surgery. Journal of the Egyptian Society of Cardio-Thoracic Surgery, 25(1):79-90.

Mostafa, E.A. (2016). Mnemonic strategy training of the elderly at risk for dementia enhances integration of information processing via cross-frequency coupling. Alzheimer's and Dementia: Translational Research and Clinical Interventions, 2(4):241-249.

Nelson, P.M.; Burns, M.K; Kanive, R. \& Ysseldyke, J.E. (2013). Comparison of a math fact rehearsal and a mnemonic strategy approach for improving math fact fluency. Journal of School Psychology, 51(6):659-667.

Ruth, L; Palmer, L; Phillips, W; Catolico, O \& Sweeny,N. (2013) Testing a Mnemonic on Response Skills during. Simulated Codes Clinical Simulation in Nursing, 9(6):191-197. 
Rawendy, D; Yi Ying.; Arifin, Y. \& Rosalin, K. (2017). Design and Development Game Chinese Language Learning with Gamification and Using Mnemonic Method. Procedia Computer Science, 116(23):61-67.

Richter, F. R.; Chanales, A. J. H. \& Kuhl, B. A. (2016). Neurolmage Predicting the integration of overlapping memories by decoding mnemonic processing states during learning. Neurolmage, 124(1): 323-335.

Setiawati, H. \& Corebima, A D. (2018). Improving Students Metacognitive Skills through Science Learning by Integrating PQ4R and TPS Strategies at A Senior High School in Parepare, Indonesia. Journal of Turkish Science Education, 15(2):96-106.

Siahaan, G. (2017). Upaya Meningkatkan Hasil Belajar PKn dengan Menerapkan model Pembelajaran Mnemonic", Jurnal Global Edukasi, 1(3):457-460.

Simon, S. S.; Hampstead, B. H. \& Bottino, C. M. D. (2017). Transfer Effect After Mnemonic Strategy Training In Amnestic Mild Cognitive Impairment: Evidence From A Randomized, Single-Blind Study. Alzheimer's \& Dementia, 13(7): 900.

Trianto. (2007). Model-model Pembelajaran Inovatif Beorientasi Kontruktivistik. Jakarta: Prestasi Pustaka

Vlasceanu, M. \& Coman, A. (2018). Mnemonic accessibility affects statement believability: The effect of listening to others selectively practicing beliefs. Cognition.180:238-245

Wahyuningsih, A.N. (2012). The Development of illustrated Comics for nervous System Learning Material for the Learning Activity implementing PQ4R Strategy). Journal of Innovative Science Education. JISE, $1(1): 19-27$

Wyra, M.; Lawson, M. J. \& Hungi, N. (2007). The mnemonic keyword method: The effects of bidirectional retrieval training and of ability to image on foreign language vocabulary recall. Learning and Instruction. 17(3):360-371.

Yaumul, V. (2016). Profil Retensi Pengetahuan Peserta didik SMA Pada Materi Sistem Pertahanan Tubuh Melalui Metode Membaca SQ5R, Jurnal Bio Education, 1(1):55-63. 